\title{
Molecular Characterization of Potent Biocontrol Isolates of Trichoderma asperellum and Pseudomonas fluorescens from Tomato Rhizosphere
}

\author{
Raghuveer Singh ${ }^{1 *}$, N. Tiameren $\mathrm{Ao}^{2}$, Valenta Kangjam ${ }^{2}$, Susanta Banik ${ }^{2}$, Susheel \\ Kumar Sharma ${ }^{3}$, G. Rajesha ${ }^{4}$, Monika Hajong ${ }^{4}$, C. Lalhruaitluangi ${ }^{2}$ and L. Daiho ${ }^{2}$
}

${ }^{1}$ ICAR Research Complex for NEH Region, Arunachal Pradesh Centre, Basar-791101, Arunachal Pradesh, India

${ }^{2}$ Department of Plant Pathology, SASRD, Nagaland University, Medziphema-797106, Nagaland, India

${ }^{3}$ ICAR Research Complex for NEH Region, Manipur Centre, Lamphelpat-795004, Imphal, Manipur, India

${ }^{4}$ ICAR Research Complex for NEH Region, Nagaland Centre, Medziphema-797106, Nagaland, India

*Corresponding author

\section{Keywords}

Tomato;

Trichoderma;

Pseudomonas;

ITS region;

Phylogenetic analysis

\section{Article Info}

Accepted:

15 December 2019

Available Online:

20 January 2020
The potent native bioagents isolated from tomato rhizosphere have high antagonistic potential against Phytophthora infestans. Molecular characterization of fungal isolates (T-11 and T-14) was performed by using Internal Transcribed Spacer (ITS) region of $18 \mathrm{~S}$ rRNA sequence. The sequence analyses of two isolates (MK928414 and MK928417), showed 100\% similarity with Trichoderma asperellum during BLAST analysis. The phylogeny tree constructed by using sequence analysis showed the formation of cluster along with $T$. asperellum and both the isolates were identified as $T$. asperellum. The rhizospheric potential bacterial isolates (Pf-2 and Pf-3) were isolated and characterized at molecular level. Bacterial isolates were identified as Pseudomonas fluorescens by using 16S-23S rRNA intervening sequence specific ITS1 and ITS2 primers. The sequence analyses of two isolates showed 89.76-92.67\% similarity with $P$. fluorescens during BLAST analysis and received the NCBI GenBank accession number of MN783298 and MN783297 for Pf-2 and Pf-3 isolates respectively. These isolates were further confirmed by phenotypic characteristics. It is inferred from the present study, that taxonomical knowledge on bioagents is important for accurate identification and molecular characterization of potential biocontrol species. This is to undeniably avoid potential risk of introducing an unknown bacterial and fungal species into the rhizosphere of a given ecosystem. 


\section{Introduction}

Plants are colonized by an astounding number of microorganisms that can reach cell densities much greater than the number of plant cells. Microbial diversity plays a pivotal role for maintaining the ecosystem functions which support life on earth. Microbial interactions with plants together with cell signalling are known as plant microbial interaction (Hooper and Gordon, 2001). This interaction results in revealing important information and application in the field of biocontrol and biofertilizers. In the recent period, their importance in different capacities has been highlighted such as induced systematic resistance, disease management and plant growth improvement (Rodriguez et al., 2004; Vacheron et al., 2013). There is still more to be discovered which may be linked to unearthing novel discoveries, identification, studying their potential role in biological disease management, biodegradation and plant growth promotions (Stockwell et al., 2011).

The use of microbial biocontrol technologies in agriculture is currently expanding quite rapidly with the identification of new fungal and bacterial bioagents, which are more effective for disease management as well as plant growth promotion. Trichoderma spp. and Pseudomonas spp. are very difficult to distinguish morphologically, so molecular methods including DNA sequencing and genealogical concordance phylogenetic species recognition using several unliked genes are needed to give accurate identification (Druzhinina et al., 2006). Therefore, ITS region of $18 \mathrm{~S}$ rRNA and 16S$23 \mathrm{~S}$ rRNA were one of the most consistent targets to identify an unknown fungal and bacterial isolates at the species level respectively (Rifai, 1969). Limited studies are available on the molecular characterization of native isolates of bioagents in Nagaland, India. The present study was undertaken to characterize and identify the potent bioagents isolates from tomato rhizosphere by morphological and molecular methods that play an important role in plant growth promotion and disease management.

\section{Materials and Methods}

\section{Native bioagents}

The samples of rhizospheric soil were collected from healthy tomato from different location of Nagaland, India. The collected samples were used for isolation of native bioagents by soil dilution plate technique (Waksman, 1927).

\section{Potential bioagents}

Based on antagonistic capabilities of native isolates against Phytophthora infestans, the tomato late blight pathogen and elucidation of their various biocontrol mechanisms, the potent bioagents were identified as bacterial isolates (Pf-2 and Pf-3) and fungal isolates (T11 and $\mathrm{T}-14$ ) for further characterization.

\section{Molecular characterization}

\section{Fungal growth condition}

Four mycelial disc (5 mm diameter) from six days old cultures of fungal isolates (T-11 and $\mathrm{T}$-14) were transferred to $100 \mathrm{ml}$ of potato dextrose broth medium (HIMEDIA) and incubated at $28{ }^{\circ} \mathrm{C}$ for six days. The mycelium was filtered through a sterile whatman filter paper-42, washed twice with sterile distilled water, drained on filter paper and ground using a mortar and pestle in liquid nitrogen.

\section{Extraction of DNA}

The genomic DNA of fungal isolates (T-11 and $\mathrm{T}-14$ ) was extracted from $200 \mathrm{mg}$ of ground mycelia using commercial DNA 
isolation kit (GCC Biotech, India). Bacterial cultures (Pf-2 and Pf-3) were grown in $5 \mathrm{ml}$ King's B broth at $27^{\circ} \mathrm{C}$. Cells were harvested after $72 \mathrm{~h}$ old culture broth and processed immediately for DNA isolation by following standard procedure (Sambrook et al., 1989).

The quality and concentration of the genomic DNA was assessed using a spectrophotometer (Shimadzu UV-160), which measured the UV absorbance at 260 and $280 \mathrm{~nm}$ and computed the 260/280 absorbance ratio. Finally the DNA was resuspended in $50 \mu \mathrm{l}$ of TE buffer and concentration of the genomic DNA was quantified by use of ethidium bromide fluorescens.

\section{PCR amplification of ITS region}

The universal primer ITS4 and ITS6 was used for amplifying and sequencing the fungal rDNA ITS region (White et al., 1990). Amplification reaction was prepared in a total volume of $50 \mu \mathrm{l}$ containing $4 \mu \mathrm{l}$ of $5 \mathrm{x}$ Gitschier buffer, 2.5 DNA polymerase ( $5 \mathrm{U}^{\mathrm{N}} \mathrm{l}^{-}$

${ }^{1}$ ) (Banglore Genie, India). 50 pmol each of forward (ITS6) and reverse (ITS4) primers and $2.5 \mu \mathrm{l}$ of $50 \mathrm{ng}$ DNA template. Thermal cycling (Eppendorf Master Cycler, German) consisted of a $2 \mathrm{~min}$ initial denaturation at 95 ${ }^{0} \mathrm{C}$, followed by 40 cycles of elongation (denaturation at $94{ }^{0} \mathrm{C}$ for $1 \mathrm{~min}$, annealing at $55{ }^{\circ} \mathrm{C}$, for $1 \mathrm{~min}$ and extension at $72{ }^{0} \mathrm{C}$ for 1 min) and ending with a final extension at 72 ${ }^{0} \mathrm{C}$ for $10 \mathrm{~min}$.

To confirm isolates as Pseudomonas spp., 16S-23S rRNA intervening sequence specific ITS1F and ITS2R primers were used to get an amplicon size of 560 bp (Rameshkumar et al., 2002). PCR reactions were carried out in $20 \mu 1$ reaction mixture $25 \mathrm{ng} / \mu \mathrm{l}$ of template DNA $(4.00 \mu \mathrm{l}), 50 \mathrm{pcM}$ of primers $(4.0 \mu \mathrm{l})$, red dye PCR master mix (2X) (Bangalore Genei, India) $(8.00 \mu \mathrm{l})$ and double sterilized distilled water $(4.00 \mu \mathrm{l})$. DNA samples were amplified on DNA thermal cycler (Eppendorf Master Cycler, German) using the PCR conditions 92 ${ }^{\circ} \mathrm{C}$ for $4 \mathrm{~min}$., $28^{\circ} \mathrm{C}$ for $1 \mathrm{~min}$. and $72{ }^{\circ} \mathrm{C}$ for 2 min. The total number of cycles was 40 with the final extension time of $10 \mathrm{~min}$.

The PCR products were separated by electrophoresis (at $75 \mathrm{~V} \mathrm{~cm}^{-1}$ for $50 \mathrm{~min}$ ) on 1.5 per cent agarose gel with $1 \mathrm{x}$ Tris acetate EDTA buffer. The gel was viewed and image captured using gel documentation system (Alpha Innotech Corporation, San Leandro, California).

\section{Sequencing and data analysis}

PCR products of $18 \mathrm{~S}$ rRNA gene of fungal isolates (T-11 and T-14) and 16S-23S rRNA gene of bacterial isolates (Pf-2 and Pf-3) obtained through amplification with specific primer were freeze dried in a lyophilizer (CHRIST ALPHA I-2LD) and sent for custom sequencing using same upstream and downstream primers used for the amplification of 18S rRNA and 16S-23S rRNA gene (Eurofins Genomics India, Pvt. Ltd., Bengaluru, India). The gene sequences were assembled using BioEdit software ver 7.1 (Hall, 1999).

\section{Phylogenetic analysis}

For species identification, fungal and bacterial sequences were submitted to BLAST (Basic local alignment search tool) interface in NCBI (http://blast.ncbi.nlm.nih.gov). All positions containing gaps and missing data were eliminated from the dataset. Phylogenetic analysis was performed in MEGA 5.2 (Tamura et al., 2004). The nucleotide sequences of ITS rDNA gene were deposited in National Centre for Biotechnology Information (NCBI) GenBank. The stability of the relationship was assessed by bootstrap analysis by performing 100 re-samplings for the tree topology of the neighbor-joining method. 
Phenotypic characterization of potential bacterial isolates

Phenotypic characterization of potential bacterial isolates (Pf-2 and Pf-3) were carried out through Gram's staining technique, colony morphology, fluorescens and microscopic observations. Microscopic observations were recorded on the basis of their shape, colour, opacity and mucosity. Individual potential isolates were streaked on the King's B medium plates and incubated at $28 \pm 2{ }^{\circ} \mathrm{C}$ for 4 days to record colony characteristics and it was based on their shape, size, colour and mucosity (Garrity et al., 2005).

\section{Results and Discussion}

\section{Molecular characterization and phylogenetic analysis of potential fungal isolates}

Molecular identification of potential fungal isolates (T-11 and T-14) was performed by using Internal Transcribed Spacer (ITS) region of 18S rRNA sequence. The PCR single DNA fragment of approximately $600 \mathrm{bp}$ amplicon size was recorded in both the Trichoderma isolates (Fig 1). The sequence analyses of two isolates showed $100 \%$ similarity with Trichoderma asperellum during BLAST analysis and received the NCBI GenBank accession number of MK928414 and MK928417 for T-11 and T-14 isolates respectively (Table 1). The phylogeny tree was constructed by using sequence analysis showed the formation of cluster along with $T$. asperellum and both the isolates were identified as T. asperellum (Fig 3).

\section{Identification of potential bacterial isolates}

Molecular characterization of potential bacterial rhizospheric isolates (Pf-2 and Pf-3) was performed by using Internal Transcribed Spacer (ITS) region of 16S-23S rRNA intervening sequence specific ITS1 and ITS2 primers (Fig 2). The sequence analyses of two isolates showed $89.76-92.67 \%$ similarity with $P$. fluorescens during BLAST analysis and received the NCBI GenBank accession number of MN783298 and MN783297 for Pf2 and Pf-3 isolates respectively (Table 1). The phylogeny tree was constructed by using sequence analysis showed the formation of cluster along with $P$. fluorescens and both the isolates were identified as $P$. fluorescens (Fig 4). These isolates were further confirmed by Gram reaction, colony morphology, cell shape and fluorescens. They were observed as Gram negative, rod shaped cells, creamy mucoid colony with smooth edges and produced yellow-green fluorescent pigmentation under ultraviolet (UV) light. Hence, both isolates were identified as $P$. fluorescens.

The rhizosphere microbes perform different functions in many capacities and under different situations. Nature has placed them in the subsurface and is largely untapped in certain soils where specific conditions prevail (Naveed et al., 2014). Considering this and many open ended questions, we isolated native bioagents from tomato rhizosphere. Molecular phylogeny extends our knowledge regarding organism relationships and provides the foundation for the conventional identification techniques (Singh et al., 2007).

In the present investigation, the ITS sequence of potent native fungal and bacterial viz., Trichoderma and Pseudomonas bioagents was chosen for the molecular characterization. It has been showed to be more informative and accurate method of identification about genus of Trichoderma and Pseudomonas (KullnigGradinger et al., 2002). The ITS region of $18 \mathrm{~S}$ rRNA and 16S-23S rRNA were one of the most consistent targets to identify unknown fungal and bacterial isolates at the species level respectively (Rifai, 1969; Kindermann et al., 1998; Druzhinina et al., 2006). The phenotypic characterization of bacterial isolates was explored for identification. 
Table.1 Isolate number, NCBI GenBank accession number and similarity per cent of potent biocontrol isolates of $T$. asperellum and $P$. fluorescens from tomato rhizosphere

\begin{tabular}{|c|c|c|c|c|}
\hline $\begin{array}{l}\text { Isolate } \\
\text { No. }\end{array}$ & $\begin{array}{c}\text { Accession } \\
\text { No. }\end{array}$ & Primers and their sequence & $\begin{array}{l}\text { Base } \\
\text { pair }\end{array}$ & $\begin{array}{c}\text { Similarity } \\
(\%)\end{array}$ \\
\hline T-11 & MK928414 & $\begin{array}{c}\text { Forward (ITS6) } \\
\text { 5'-GAAGGTGA AGTCGTAACA AGG-3' } \\
\text { Reverse (ITS4) } \\
\text { 5'-TCCTCCGCTTATTGATA TG C-3' }\end{array}$ & 603 & $\begin{array}{c}\text { T. asperellum } \\
(100 \%)\end{array}$ \\
\hline T-14 & MK928417 & $\begin{array}{c}\text { Forward (ITS6) } \\
\text { 5'-GAAGGTGA AGTCGTAACA AGG-3' } \\
\text { Reverse (ITS4) } \\
\text { 5'-TCCTCCGC TTATTGATA TG C-3' }\end{array}$ & 604 & $\begin{array}{c}\text { T. asperellum } \\
(100 \%)\end{array}$ \\
\hline Pf-2 & MN783298 & $\begin{array}{c}\text { Forward (ITS1) } \\
\text { 5'-AAGTCGTAACAAGGTAG-3' } \\
\text { Reverse (ITS2) } \\
\text { 5'-GACCATATATAACC CCAAG-3' }\end{array}$ & 621 & $\begin{array}{l}\text { P. fluorescens } \\
(92.67 \%)\end{array}$ \\
\hline Pf-3 & MN783297 & $\begin{array}{c}\text { Forward (ITS1) } \\
\text { 5'-AAGTCGTAACAAGGTAG-3' } \\
\text { Reverse (ITS2) } \\
\text { 5'-GACCATATATAACC CCAAG-3' }\end{array}$ & 533 & $\begin{array}{l}\text { P. fluorescens } \\
(89.76 \%)\end{array}$ \\
\hline
\end{tabular}

Fig.1 PCR amplification of fungal isolates by using ITS6 and ITS4 of 18S rRNA

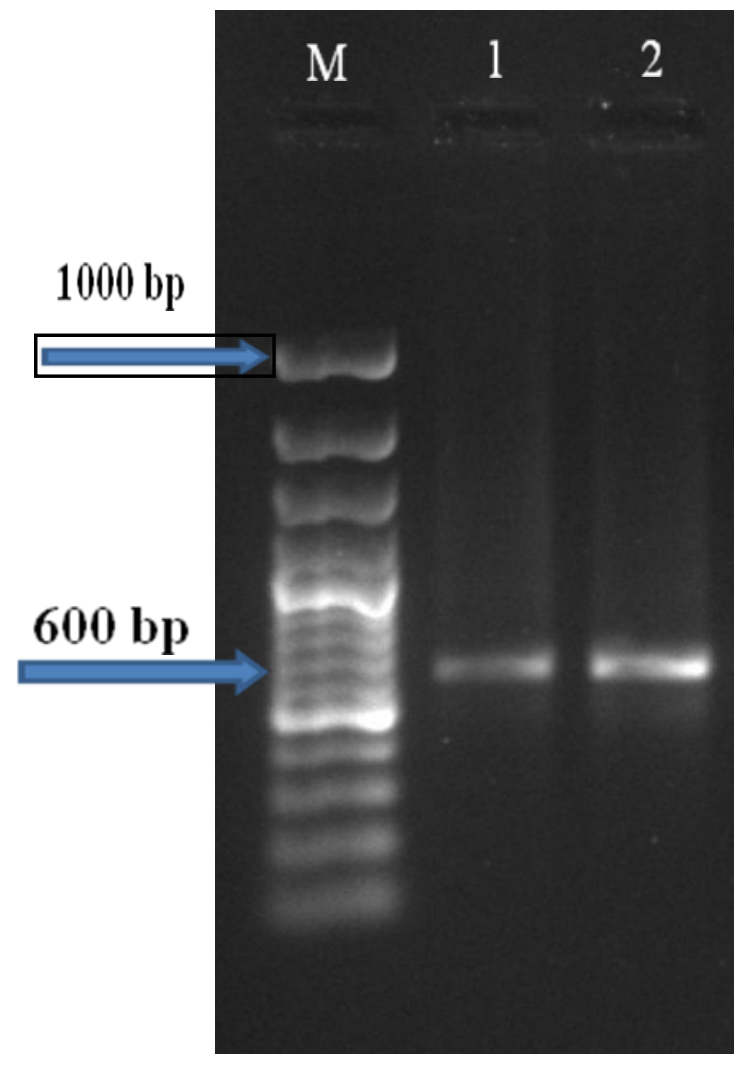

M=100 bp DNA ladder; lane 1 (T-11) and lane 2 (T-14) 
Fig.2 PCR amplification of bacterial isolates by using ITS1 and ITS2 of 16S-23S rRNA

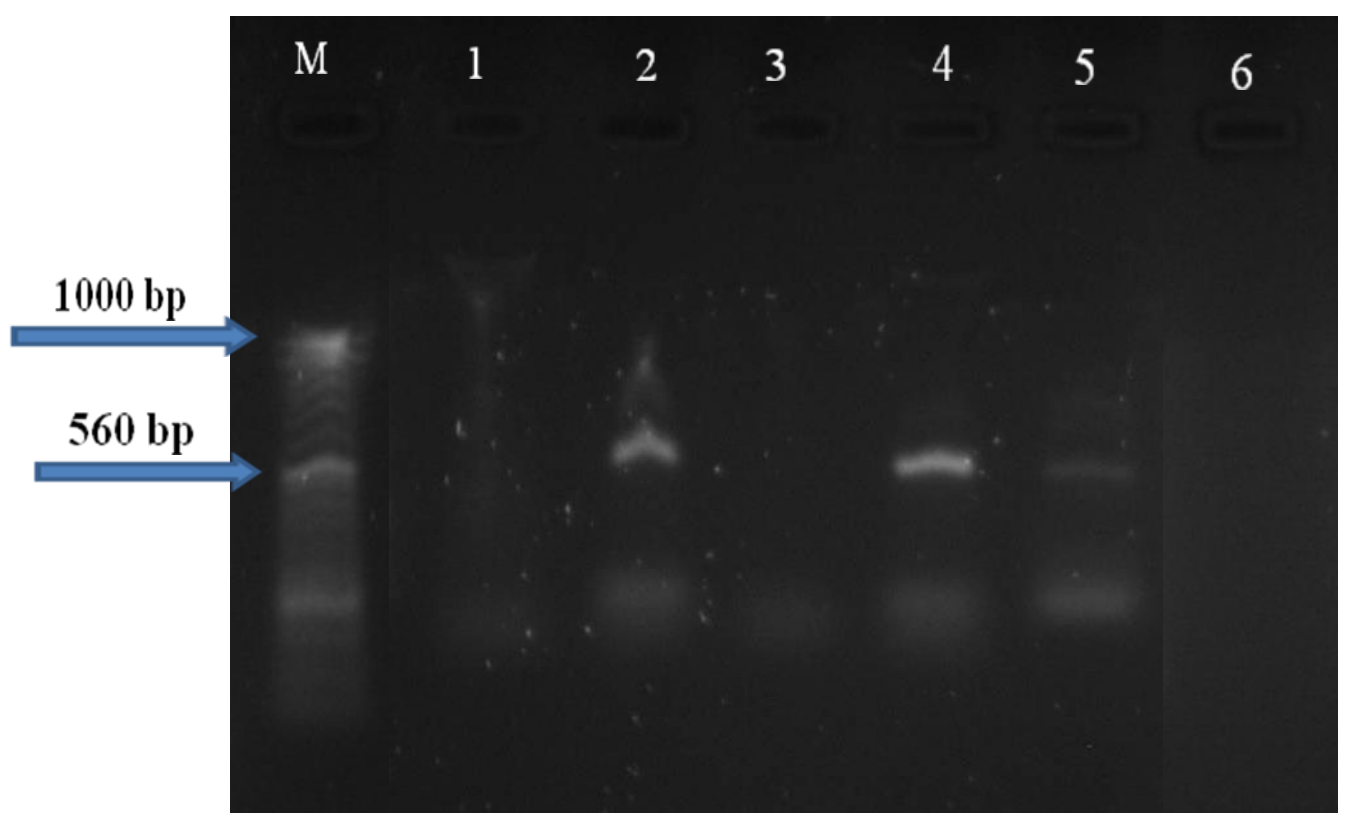

M=50 bp DNA ladder; lane 1, 3, 5 (other samples); lane 2 (Pf-2); lane 4 (Pf-3) and lane 6 (Negative control)

Fig.3 Phylogenetic tree based on ITS region of 18S rRNA sequences and the number given over branches indicate bootstrap coefficient

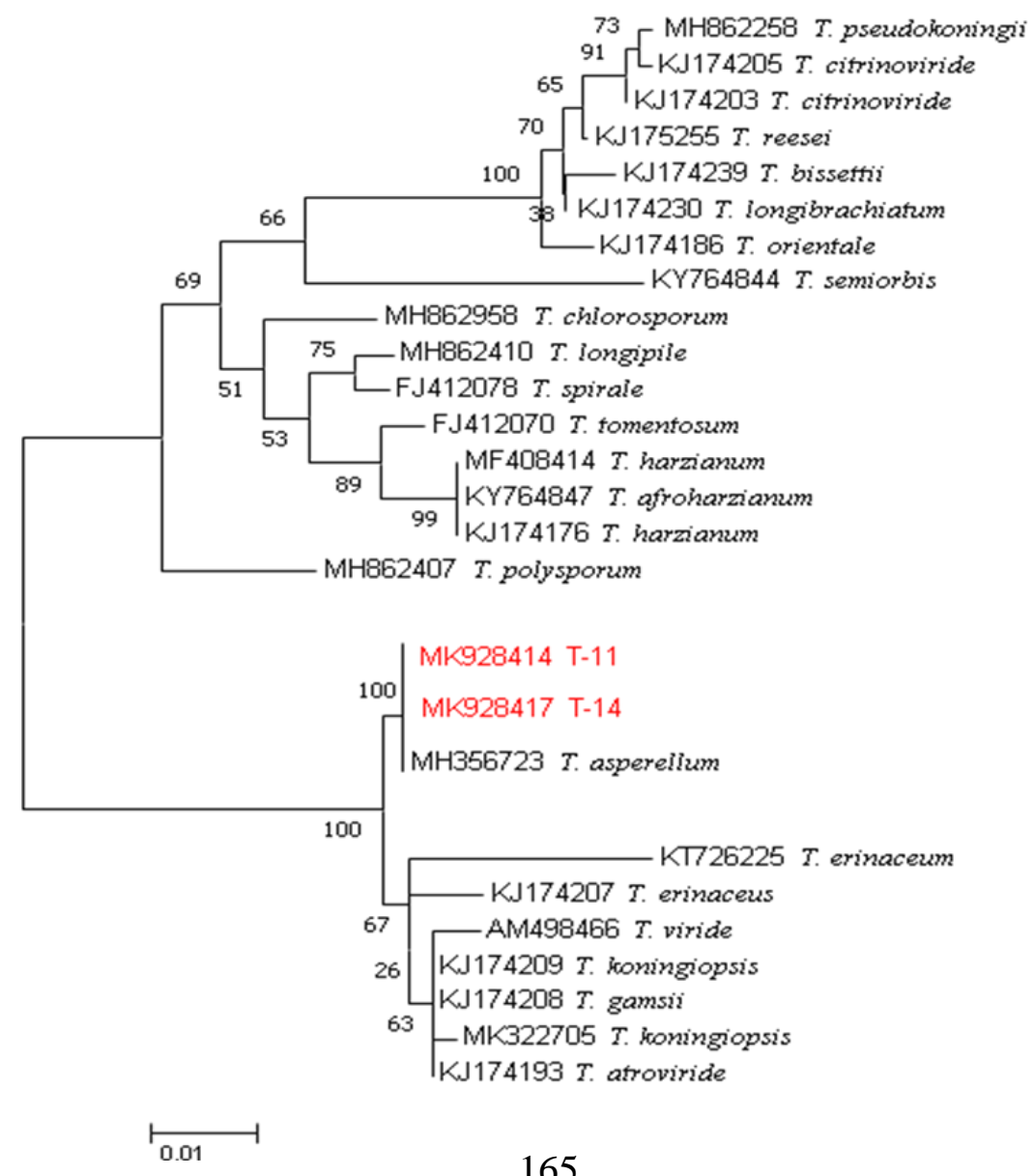


Fig.4 Phylogenetic tree based on ITS region of 16S-23S rRNA sequences and the number given over branches indicate bootstrap coefficient

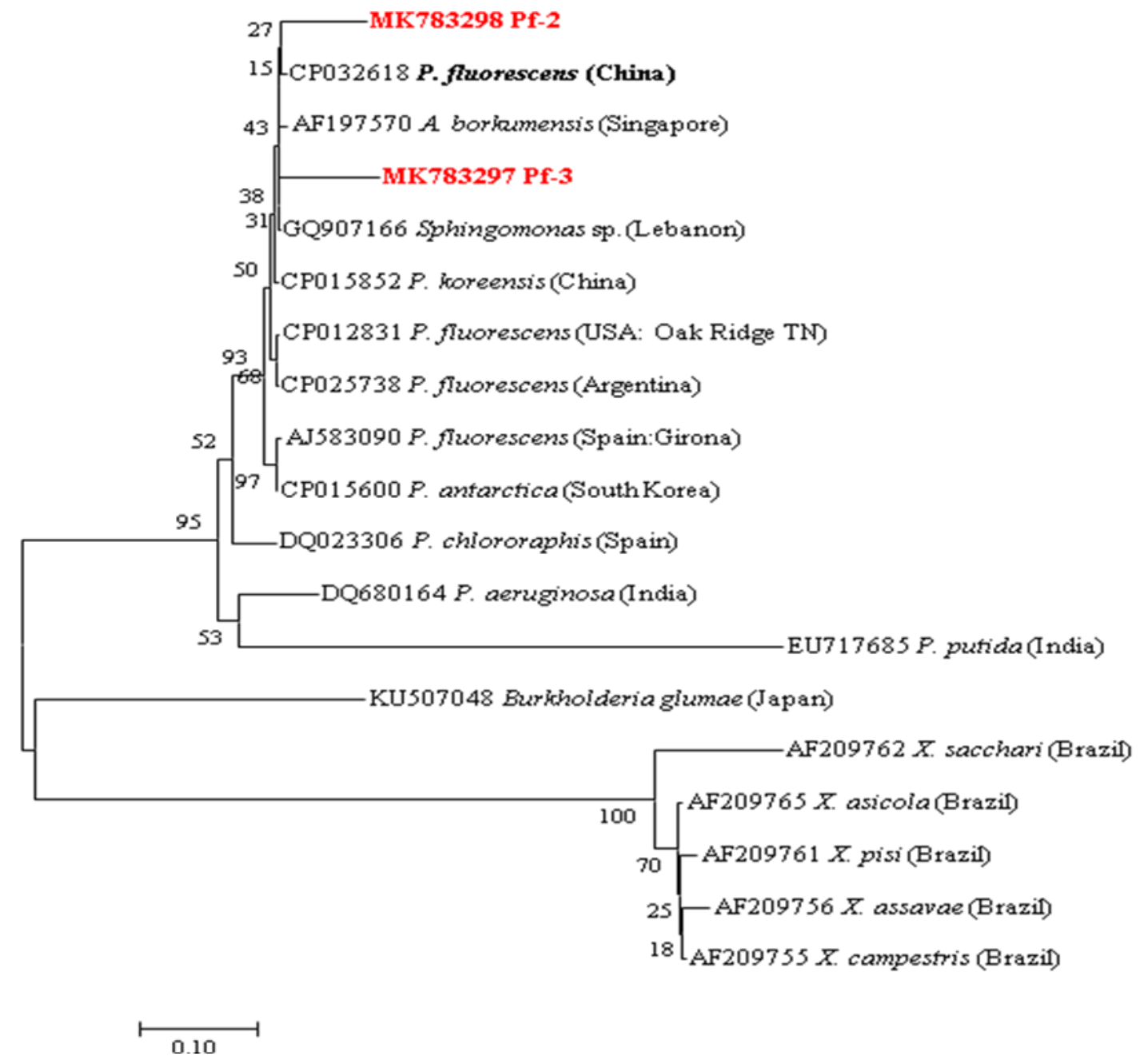

Garrity et al., (2005) confirmed the identity of fluorescent pseudomonas by Gram's staining technique, colony morphology, fluorescens and cell shape. Singh et al., (2017) also identified $P$. fluorescens on the basis of their cultural, morphological and biochemical characters.

It is inferred from the present study, that taxonomical knowledge on bioagents is important for accurate identification and molecular characterization of potential biocontrol species. This is to undeniably avoid potential risk of introducing an unknown bacterial and fungal species into the rhizosphere of a given ecosystem.
The attempt made in the present study to identify indigenous potent bioagents based on molecular and phenotypic analysis gives us an edge to have more cultured microorganisms with their taxonomy from indigenous environments. Such bioagents can also be used as a source of gene(s) that can control diseases in different crop species through genetic transformation.

\section{References}

Druzhinina, I. S., Kopchinskiy, A. G. and Kubicek, C. P. 2006. The first one hundred of Trichoderma species is characterized by molecular data. Mycoscience. 47: 55-64. 
Garrity, G.M., Brenner, D.J., Krieg, N.R. and Staley, J.T. 2005. Bergey's Manual of Systematic Bacteriology. $2^{\text {nd }}$ Edn. Springer, USA. 323-359.

Hall, T.A., 1999. BioEdit: a user-friendly biological sequence alignment editor and analysis program for windows 95/98/NT. Nucleic Acids Symposium Ser. 41: 9-98.

Hooper, L.V. and Gordon, J.I. 2001. Commensal host-bacterial relationships. Gut. Science. 292: 1115-1118.

Kindermann, J., El-Ayouti, Y., Samuels, G. J. and Kubicek, C. P. 1998. Phylogeny of the genus Trichoderma based on sequence analysis of the ITS region 1 of the rDNA clade. Fungal Genetics and Biology. 24: 298-309.

Kullnig-Gradinger, C. M., Szakacs, G. and kubicek, C. P. 2002. Phylogeny and evolution of the genus Trichoderma: amultigene approach. Mycological Research. 106 (7): 757-767.

Naveed, M., Mubeen, S., Khan, S., Ahmed, I., Khalid, N., Suleria, H.A.R., Bano, A. and Mumtaz, A.S. 2014. Identification and characterization of rhizospheric microbial diversity br $16 \mathrm{~S}$ ribosomal RNA gene sequencing. Brazilian Journal of Microbiology. 45 (3): 517-518.

Rameshkumar, N., Thirumalai Arasan, V. and Gunasekaran, P. 2002. Genotyping of antifungal compounds producing plant growth promoting rhizobacteria, Pseudomonas fluorescens. Current Science. 82: 1436-1466.

Rifai, M. A. 1969. A revision of the genus Trichoderma. Mycological Paper. 116: 1116.

Rodriguez, H., Gonzalez, T., Goire, I. and Bashan, Y. 2004. Gluconic acid production and phosphate solubilization by the plant growth-promoting bacterium Azospirillum spp. Naturwissenschaften. 91: 552-555.

Sambrook, J., Fritsch, F.E. and Maniatis, T.A. 1989. Molecular cloning: a laboratory manual, $2^{\text {nd }}$ ed. Cold Spring Harbor
Laboratory Press. pp. 545.

Singh, S., Chandra, R., Patel, D.K. and Rai, V. 2007. Isolation and characterization of novel Serratia marcescens (AY927692) for pentachlorophenol degradation from pulp and paper mill waste. World Journal of Microbiology and Biotechnology. 23: 1747-1754.

Singh, S., Dutta, U., Bhat, A.K., Gupta, S., Gupta, V. and Jamwal, S. 2017. Morphocultural and biochemical identification of Pseudomonas spp. isolated from the rhizosphere of different vegetable crops and study its efficacy on Solanum melongena. Journal of Pharmacognosy and Phytochemistry. 6 (2): 22-28.

Stockwell, V.O., Johnson, K.B., Sugar, D. and Loper, J.E. 2011. Mechanistically compatible mixtures of bacterial antagonists improve biological control of fire blight of pear. Phytopathology. 101: 113-123.

Tamura, K., Nei, M. and Kumar, S. 2004. Prospects for inferring very large phylogenies by using the neighbor-joining method. Proceedings of the National Academy of Sciences (USA). 101: 1103011035.

Vacheron, J., Desbrosses, G., Marie-Lara, B., Touraine, B., Mo€enne-Loccoz, Y., Muller, D., Legendre, L., Wisniewski-Dye, F. and Prigent-Combaret, C. 2013. Plant growth promoting rhizobacteria and root system functioning. Frontiers in Plant Science. 4: 356.

Waksman, S. M. 1927. Principles of soil microbiology. Williams and Wikins Co. Baltimore. 897.

White, T.J., Bruns, T., Lee, S. and Taylor, J. 1990. Amplification and direct sequencing of fungal ribosomal RNA genes for phylogenetics. In: PCR protocols: a guide to methods and applications (eds. M.A., Innis, D.H. Gelfand, J.J. Sninsky, T.J. White). Academic Press, San Diego. 315322. 


\section{How to cite this article:}

Raghuveer Singh, N. Tiameren Ao, Valenta Kangjam, Susanta Banik, Susheel Kumar Sharma, G. Rajesha, Monika Hajong, C. Lalhruaitluangi and Daiho, L. 2020. Molecular Characterization of Potent Biocontrol Isolates of Trichoderma asperellum and Pseudomonas fluorescens from Tomato Rhizosphere. Int.J.Curr.Microbiol.App.Sci. 9(01): 160-168. doi: https://doi.org/10.20546/ijcmas.2020.901.018 